\title{
Leadership Styles of Nurse Managers and Job Satisfaction of Staff Nurses: Correlational Design Study
}

\author{
Bander Albagawi, PhD \\ University of Hail, Kingdom of Saudi Arabia
}

Doi: 10.19044/esj.2019.v15n3p254 URL:http://dx.doi.org/10.19044/esj.2019.v15n3p254

\begin{abstract}
Aim: This study aimed to determine the relationship between the leadership styles of nurse managers and the job satisfaction of staff nurses in hospital settings in Ha'il City, Saudi Arabia. Methods: The study employed a quantitative correlational research design. The research respondents were staff nurses working under the supervision of nurse managers, who they evaluated for leadership styles, using the multifactor leadership questionnaire developed by Bass and Avolio (1992). At the same time, the staff nurses rated their job satisfaction using the work quality index questionnaire by Whitley and Putzier (1994). Purposive sampling was employed to generate samples of staff nurses from four governmental hospitals in Ha'il City. Findings: The leadership styles of nurse managers, as perceived by the staff nurses, revealed that they were often displaying transformational leadership $(M=2.88)$, sometimes displaying transactional leadership $(M=2.31)$ and occasionally displaying laissez-faire leadership $(M=1.38)$. The staff nurses' level of job satisfaction yielded responses of 'somewhat satisfied' for professional work environment $(M=4.78)$ and professional relationships $(M=4.95)$ and 'neutral' for autonomy $(M=4.45)$, work worth $(M=4.5)$, role enactment $(M=4.34)$ and benefits $(M=4.23)$. Transformational leadership correlated with the level of job satisfaction, and yielded an $r$-value of 0.258 , which connoted a low correlation, with a $p$-value of 0.000 . There was a significant relationship between the nurse managers' transformational leadership style, as perceived by the staff nurses, and the staff nurses' level of job satisfaction. This implies that, because the nurse managers often manifested transformational leadership, the staff nurses' level of job satisfaction slightly increased. Moreover, there was a significant relationship between laissez-faire leadership and level of job satisfaction ( $p$-value of 0.006), with a correlation coefficient of -0.204 indicating a negative correlation between variables. Conclusion: The nurse managers displayed transformational leadership behaviour more than transactional and laissez-faire leadership styles. The staff nurse
\end{abstract}


respondents were somewhat satisfied with their work environment and professional relationships; however, they were unsure whether they were satisfied with factors such as autonomy, work worth, role enactment and benefits - as reflected in their neutral responses. Transformational leadership styles positively correlated with the nurses' job satisfaction.

Keywords: Transactional leadership, transformational leadership, laissezfaire leadership, job satisfaction, work quality index

\section{Introduction}

Nursing professionals and services are in increasing demand because of the increasing ageing populations in every country. This increasing demand has also arisen because of the stability, peace and order around the world; the less volatile situations in different regions; and the development of new technology to cure diseases (Al-Omari, Abdelwahed, \& Alansari, 2015; Botelho, 2015). The Kingdom of Saudi Arabia government has been receiving an influx of nursing professionals from Asian countries and nearby regions because of its advanced technology in medical facilities, higher salaries and other working conditions that encourage the workforce to stay and work in the Kingdom (Alboliteeh, 2015; Breakey, Corless, Meedzan, \& Nicholas, 2015). However, despite these amenities and benefits, the Kingdom's nursing population is not yet at the required level, as evidenced by Ministry of Health's continued recruitment of nursing professionals by the thousands. Year after year, nursing professionals continue to leave the Kingdom, taking their skills and experience to find work in other countries. Despite the many opportunities and financial guarantees offered to nursing professionals in the Kingdom, the exodus continues. This has raised a number of questions, including: Are there opportunities for improvement and career advancement available in the Kingdom? Is there a security of tenure being practised in the Kingdom? Are nursing managers able to motivate the workforce to stay in the Kingdom? Are nurse managers practising the art of leadership, or are they the cause of nursing professionals continuing to exit the Kingdom (Breakey, Corless, Meedzan, \& Nicholas, 2015). Other potential causes for this nursing exodus are not within the realm of this study, which focuses on nursing managers and their leadership styles to motivate the workforce and create a work environment that provides job satisfaction for nursing professionals to stay longer, with their skills and experience, for the betterment of the nursing services rendered to their clientele.

Leadership is an art and discipline of guiding, directing, motivating and inspiring a group or organisation towards the achievement of common goals (Alboliteeh, 2015). Different types of leadership styles exist in work environments, with various advantages and disadvantages for each leadership 
style. The culture and goals of an organisation determine which leadership style best fits the institution. Some institutions offer several leadership styles within the organisation, depending on the tasks required to achieve departmental needs (Al-Omari, Abdelwahed, \& Alansari, 2015). Nursing leadership is important in today's healthcare environment, which is experiencing unprecedented intense reform (American Nurses Credentialing Center, 2012). Nurse leadership requires effective communication, selfawareness and social awareness (Taft, 2009). Unlike yesterday's leadership requirements for stabilisation and growth, today's leaders must transform their organisation's values, beliefs and behaviours (American Nurses Credentialing Center, 2012). Nurse managers are responsible for creating an environment that supports professional practice and employee engagement. They must encourage personal development and professional growth among staff.

A number of studies from a variety of cultural contexts and settings have investigated the conceptual framework involving leadership styles and teacher/faculty job satisfaction to examine the relationship between them. These studies revealed this relationship to be significant (Amin, Shah, \& Tatlah, 2013; Bogler, 2001; Mosadeghrad \& Yarmohammadian, 2006). The leadership style that the leaders of an institution choose to exercise is underpinned by the culture and context of that institution, which may affect the teacher's/faculty's job satisfaction (Al-Omari, 2008). Thus, it may be inferred that leadership style can result in a satisfied or dissatisfied teacher/faculty member. This indicates that leadership style is an independent variable, while job satisfaction is a dependent variable. These two variables are investigated in the present study. A satisfied teacher/faculty member is more likely to deliver enhanced performance, and could be a prime element in improving the quality and performance of an educational institution (Chen \& Silverthorne, 2005; Toker, 2011). Further, 'teachers' satisfaction from the job is highly important for the nexus between teachers and students, for satisfied teachers will be more enthusiastic about investing time and energy in teaching their students' (Bogler, 2001). An appropriate leadership style is more likely to enhance job satisfaction among the teacher/faculty (Amin, Shah, \& Tatlah, 2013) to potentially increase their performance (Madlock, 2008).

During times of dramatic organisational changes in complex and complicated health systems, the nurse leader's role is challenging and difficult. Effective nurse leaders must understand clinical practice and collaborate with leaders in other disciplines to improve patients' quality of life, transform healthcare systems and inspire the next generation of leaders (Clavelle, Drenkard, Tullai-McGuinness, \& Fitzpatrick, 2012). The style of the nurse leader can be important to encourage employees' acceptance of change and motivate employees to achieve a high quality of care (Newstrom \& Davis, 1993). 
High-quality healthcare is the most important service provided in a country. Unlike education, which begins when a child is around four or five years of age, healthcare is a service that begins even before the baby is born. The Saudi healthcare system is one of the most unique in the world. It is free of charge, and certain individuals - wealthy, middle-class and sometimes even ordinary citizens - can be given the unique opportunity to travel to other countries with better medical facilities, such as the United States, if the required medical treatment is unavailable in the Kingdom. This type of service is only provided in Saudi Arabia and five other Gulf states (Ahmad, 2013).

Saudi people have noted that the most challenging issue facing their healthcare system is the management of hospitals and medical centres. Managing a hospital is one of the most difficult and demanding jobs in the world, and only the most competent individuals should be assigned to these positions. Every feature of hospital staff should be examined carefully because, if the assets and budgets of hospitals are not managed appropriately, the healthcare system will be negatively affected (Al-Mulhim, 2013).

Job satisfaction is the level of contentment a person feels regarding his or her job. This feeling is largely based on the individual's perception of satisfaction. Job satisfaction can be influenced by a person's ability to complete required tasks, the level of communication in an organisation, and the way management treats employees. Job satisfaction falls into two levels: affective job satisfaction and cognitive job satisfaction. Affective job satisfaction refers to a person's emotional feeling about the job as a whole. Cognitive job satisfaction considers how satisfied employees feel concerning some aspect of their job, such as their wages, work hours or benefits (Styron \& Styron, 2017).

A previous study revealed that information about the relationship between perceptions of nursing leadership styles and job satisfaction can generate potential solutions for improving nurse job satisfaction and nurse retention (Perez, 2014). Moreover, Kleinman (2004) found a positive relationship between the transformational leadership style and nurse job satisfaction. Further, a study conducted by Robbins and Davidhizar (2007) indicated the effect of leadership styles on job satisfaction, yet failed to study nurses' perceptions of their managers' leadership styles and the extent of the relationship between leadership style and job satisfaction. In 2009, Jean Watson, a nurse theorist, stated that one of the most important factors affecting job satisfaction is the leadership style of the employee's manager (Despress, 2011). Moreover, as posited by Cox (2003), an improvement in job satisfaction can lead to improved patient outcomes and quality of care in hospitals. In 2007, a Joint Commission report found that $41 \%$ of employed nurses were dissatisfied with their jobs, while $43 \%$ of nurses reported feeling burnt out in their profession (Despress, 2011). Further, 22\% of nurses planned 
to leave their positions within the following year. The two factors most strongly associated with nurses' dissatisfaction were: (i) nurses not feeling a part of the decision-making process with patient care and (ii) nurses not receiving recognition for their expertise (Despress, 2011).

Effective leadership is necessary in a complex organisational situation, such as a hospital setting. Hospital leaders must know how to motivate their staff, employ performance management systems, and solve poor employee performance problems. Employees' relationship with their supervisor is a primary determinant of job satisfaction. Managers who demonstrate commitment to their employees through implementing organisational change positively influence nurse satisfaction and job engagement (Wood, 2008). These factors led to the current research, with its primary aim of determining the relationship between nurse managers' leadership styles and the job satisfaction of the staff nurses working at government hospitals in Ha'il City. This research is believed to be as an important step towards achieving the Saudi government's objective of improving and meeting the demands of the healthcare system in the region. The results of this research will provide the basis for an action plan related to leadership styles that will enhance satisfaction among staff nurses.

As nurse educators, the research investigators recognised the lack of studies related to the leadership styles of nurse managers and the job satisfaction of staff nurses in government hospitals in Ha'il City. Administrators can use the data from this study to educate nurse managers on effective leadership styles and how these styles affect the job satisfaction of staff nurses. Implementing the appropriate leadership style can increase nurse job satisfaction, thereby creating lower turnover rates in hospitals and an overall decrease in resources spent hiring and orienting new employees. Staff nurse satisfaction will be made evident to patients in the form of increased quality of patient care, which will generate increased patient satisfaction and reflect a positive view of the hospital. The hospital will also benefit from the satisfaction of staff nurses, as reflected in an increase in productivity, efficiency and improved patient outcomes.

\subsection{Statement of Purpose}

This study aimed to determine the relationship between nurse managers' leadership styles and staff nurses' job satisfaction in hospital settings in Ha'il City. To fulfil this aim, the following questions were answered:

1. What is the leadership style of the nurse managers, as perceived by their subordinates?

2. What is the level of job satisfaction of the staff nurses in terms of:

a. professional work 
b. environment

c. autonomy

d. work worth

e. professional relationships

f. role enactment

g. benefits?

3. Is there a significant relationship between the nurse managers' leadership style and the staff nurses' level of job satisfaction?

\section{Methodology:}

\subsection{Research Design}

This study employed a descriptive correlational design. Descriptive research is used to describe the characteristics of the population or phenomenon being studied. It does not answer questions about 'how', 'when' or 'why' the characteristics occurred; rather, it addresses the 'what' question. The aim and objectives of this study were based on determining the leadership style of the nurse managers and the level of job satisfaction of the staff nurses.

\subsection{Sample and Setting}

This study employed purposive sampling, and the respondents of this study were the staff nurses working in the government hospitals in Ha'il City - specifically, King Khalid Hospital, Ha'il General Hospital, the Maternity and Children's Hospital and Ha'il Mental Hospital.

\subsection{Measures}

The study respondents were provided two sets of questionnaires. First, the multifactor leadership questionnaire (MLQ) was employed to determine the leadership styles of the immediate superiors (head nurses) to whom the respondents reported. Second, the work quality index (WQI) was selected for this study because it was developed to specifically measure job satisfaction among nurses (Whitley \& Putzier, 1994).

The first research instrument was the MLQ, which was used to measure self-evaluation of leadership behaviours of nurse managers. It identified whether the nurse managers displayed transactional leadership, transformational leadership or laissez-faire leadership. The assessment scales of MLQ are as follows:

1. transformational leadership

a. idealised attributes

b. idealised behaviours

c. inspirational motivation

d. intellectual stimulation

e. individualised consideration 
2. transactional leadership

a. contingent reward

b. management by exception (active)

3. passive/avoidant

a. management by exception (passive)

b. laissez-faire.

Forty-five descriptive statements were listed, and the nurse managers assessed how frequently each statement fitted the leadership style she or he was using, rated with the following scale:

- $0=$ not at all

- $1=$ once in a while

- $2=$ sometimes

- 3 = fairly often

- 4 = frequently, if not always.

The second research instrument was the WQI, which was employed to measure the staff nurses' job satisfaction. The WQI is a 38 -item scale developed to measure the satisfaction of nurses with their work and work culture. The instrument was developed using factor analysis and maximum likelihood extraction techniques. The index contains six subscales: professional work environment, autonomy, work worth, professional relationships, role enactment and benefits.

\subsection{Ethical Considerations}

Before the study, approval was obtained from the ethics committee at the University of Ha'il, official permission was obtained from the Department of Health Affairs in Ha'il region, and written informed consent was obtained from all participants. Moreover, the participants who completed the questionnaire survey filled out an informed consent form agreeing to participate in the study. The study participants were briefed on the study purpose and process, as well as their right to withdraw participation at any time, without any adverse effect on their employment status. 
Table 1: Characteristics of the Respondents $(N=184)$

\begin{tabular}{|c|c|c|c|}
\hline Variables & & Frequency & Percentage \\
\hline \multirow[t]{4}{*}{ Hospital affiliation } & King Khalid Hospital & 83 & 45.1 \\
\hline & Ha'il General Hospital & 34 & 18.5 \\
\hline & Maternity Hospital & 47 & 25.5 \\
\hline & Mental Hospital & 20 & 10.9 \\
\hline \multirow[t]{13}{*}{ Area of assignment } & Emergency Room (ER) & 15 & 8.7 \\
\hline & $\begin{array}{l}\text { Operating Room/Surgical Unit } \\
\text { (OR/SU) }\end{array}$ & 25 & 13.6 \\
\hline & Delivery Room (DR) & 13 & 7.1 \\
\hline & Intensive Care Unit (ICU) & 33 & 17.9 \\
\hline & Obstetric Ward (OBW) & 10 & 5.4 \\
\hline & Female Medical Ward (FMW) & 10 & 5.4 \\
\hline & Female Surgical Ward (FSW) & 16 & 8.7 \\
\hline & Out Patient Department (OPD) & 21 & 11.4 \\
\hline & Trauma Centre (TC) & 6 & 3.3 \\
\hline & Special Care Baby Unit (SCBU) & 7 & 3.8 \\
\hline & BURN Unit & 6 & 3.3 \\
\hline & Kidney Unit (AKU) & 5 & 2.7 \\
\hline & Mental Ward (AW/MW/FW) & 16 & 8.7 \\
\hline \multirow[t]{4}{*}{ Age } & $20-30$ & 120 & 65.2 \\
\hline & $31-40$ & 42 & 22.8 \\
\hline & $41-50$ & 16 & 8.7 \\
\hline & $51-64$ & 6 & 3.3 \\
\hline \multirow[t]{2}{*}{ Gender } & Male & 25 & 13.6 \\
\hline & Female & 159 & 86.4 \\
\hline \multirow[t]{4}{*}{ Nationality } & Saudi & 113 & 61.4 \\
\hline & Filipino & 41 & 22.3 \\
\hline & Indian & 29 & 15.8 \\
\hline & Indonesian & 1 & 0.5 \\
\hline \multirow{3}{*}{$\begin{array}{l}\text { Educational } \\
\text { qualification }\end{array}$} & Diploma in Nursing & 82 & 44.6 \\
\hline & Bachelor of Science in Nursing & 100 & 54.3 \\
\hline & Master of Nursing & 2 & 1.1 \\
\hline \multirow[t]{2}{*}{ Training } & Yes & 30 & 16.3 \\
\hline & No & 154 & 83.7 \\
\hline \multirow[t]{3}{*}{ Years of experience } & $1-10$ & 146 & 79.3 \\
\hline & $11-20$ & 29 & 15.8 \\
\hline & $21-30$ & 9 & 4.9 \\
\hline Overseas & 1 & 57 & 31 \\
\hline experience & 2 & 127 & 69 \\
\hline
\end{tabular}

\section{Results:}

\subsection{Data Analysis}

After the data were collected, the questionnaires were checked for the completeness and consistency of the responses. Data analysis was then undertaken using the Statistical Package for the Social Sciences (SPSS) 
software. The results of the study were analysed using frequency distribution, percentage and Pearson-product moment correlation.

During a three-month period, a total of 184 staff nurses were recruited to participate in the study. Most of the respondents came from King Khalid Hospital $(n=83,45.1 \%)$, with the largest number from the ICU $(n=33$, $17.9 \%)$. The mean age of the respondents was 20 to 30 years, and the majority were female ( $n=159,86.4 \%)$. The majority were Saudi nationals ( $n=113$, $61.4 \%$ ) with a Bachelor of Science in Nursing educational qualification ( $n=$ $100,54.3 \%)$. A notably large number of respondents did not have training related to management $(n=154,83.7 \%)$. When asked about years of nursing experience, the one- to 10-year bracket comprised $79.3 \%$, and the majority of respondents had gained their nursing experience in Saudi Arabia (Table 1).

\section{What is the leadership style of the nurse managers, as perceived by their subordinates?}

Table 2: Leadership Style of the Nurse Managers as Perceived by the Staff Nurses

\begin{tabular}{|l|l|l|}
\hline Leadership style & Mean response & Remarks \\
\hline Transformational leadership & 2.88 & Fairly often \\
\hline Transactional leadership factors & 2.31 & Sometimes \\
\hline Laissez-faire leadership & 1.38 & Once in a while \\
\hline Grand mean & $\mathbf{2 . 1 9}$ & Sometimes \\
\hline Legend: $0.00-0.50 \quad$ Not at all & \\
$0.51-1.50$ & Once in a while & \\
$1.51-2.50$ & Sometimes & \\
$2.51-3.50$ & Fairly often & \\
$3.51-4.00$ & Frequently, if not always & \\
\hline
\end{tabular}

Table 2 displays the mean responses of the leadership styles of the nurse managers, as perceived by the staff nurses. The analysis indicated that the staff nurses' perceptions of their nurse managers' leadership styles were as follows. The nurse managers 'fairly often' used a transformational leadership style $(M=2.88, S D)$, 'sometimes' used a transactional leadership style $(M=2.13)$ and 'once in a while' used a laissez-faire leadership style $(M=1.38)$. The results indicated that the nurses perceived that their superiors were using a transformational leadership style more often than the transactional or laissez-faire leadership styles.

In terms of transformational leadership, the results indicated that the nurse managers fairly often influenced their subordinates through employing all five critical strategies of transformational leadership: attributed idealised influence, behavioural idealised influence, inspirational motivation, intellectual stimulation and individualised consideration $(M=2.88)$. As perceived by the staff nurses, the results implied that the nurse managers consistently employed transformational leadership when managing their staff. 
This result could be significant given that transformational leadership has the ability to encourage employees towards achieving more than what they had planned (Krishnan, 2005).

Table 2 displays the descriptive statistics of the nurse managers' leadership style in terms of transactional leadership factors, as perceived by the staff nurses. These factors include contingent reward, active management by exception and passive management by exception $(M=2.31)$. The results indicated that the staff nurses perceived the nurse managers to sometimes demonstrate contingent reward and active management by perceptions and by exception. This aligns with prior research that indicated that recognition through reward and encouragement increases employee job satisfaction (Wood \& Peccei, 1995). A study conducted at King Saud University in Riyadh revealed that nurses perceived that their supervisors more frequently used transformational and transactional, rather than laissez-faire, leadership styles. There was a positive correlation between outcome factors (effectiveness, extra efforts and satisfaction) and transformational and transactional leadership styles, and a negative correlation with the laissez-faire leadership style. There were significant differences between male and female nurses in regard to using transactional leadership style and laissez-faire leadership style. The findings provided supporting evidence that a combination of leadership styles is required to attain the desired goals, and further studies were suggested to explore the ideal leadership practices (Aboshaiqah, Hamdan-Mansour, Sherrod, Alkhaibary, \& Alkhaibary, 2014).

The current study's findings regarding the staff nurses' perceived evaluation of the nurse managers' leadership behaviour in terms of the laissezfaire leadership style revealed a mean of 1.38, which indicated 'once in a while'. The staff nurses' perception of the nurse managers' leadership style in regard to outcomes leadership revealed that all three dimensions of outcomes leadership - extra effort, effectiveness and satisfaction-were considered to be 'fairly often' evident in management leadership behaviour $(M=2.94)$. Overall, the data indicated that, among the identified leadership styles of the nurse managers, the staff nurses perceived that the nurse managers 'fairly often' displayed outcomes leadership $(M=2.94)$ and transformational leadership $(M=2.88)$ styles. Moreover, they were perceived to 'sometimes' demonstrate transactional leadership $(M=2.31)$ and 'once in a while' employ laissez-faire leadership $(M=1.38)$.

\section{What is the staff nurses' level of job satisfaction in terms of:}

- 2.1 Professional work environment (WQI numbers 1, 3 and 8)

- 2.2 Autonomy (WQI numbers 3, 4 and 5)

- 2.3 Work worth (WQI number 2)

- 2.4 Professional relationships (WQI numbers 6 and 7) 
- 2.5 Role enactment (WQI number 4)

- 2.6 Benefits (WQI number 9)?

Table 3: Staff Nurses' Level of Job Satisfaction

\begin{tabular}{|l|l|l|}
\hline Job satisfaction & Mean response & Remarks \\
\hline Professional work environment & 4.78 & Somewhat satisfied \\
\hline Autonomy & 4.45 & Neutral \\
\hline Work worth & 4.50 & Neutral \\
\hline Professional relationships & 4.95 & Somewhat satisfied \\
\hline Role enactment & 4.34 & Neutral \\
\hline Benefits & 4.23 & Neutral \\
\hline Grand mean & $\mathbf{4 . 5 4}$ & Somewhat satisfied \\
\hline Legend: $1.00-1.50$ & Very dissatisfied \\
$1.51-2.50$ & Dissatisfied & \\
$2.51-3.50$ & Somewhat dissatisfied \\
$3.51-4.50$ & Neutral & \\
$4.51-5.50$ & Somewhat satisfied \\
$5.51-6.50$ & Satisfied & \\
$6.51-7.50$ & Very satisfied & \\
\multicolumn{2}{l}{} \\
\hline
\end{tabular}

Table 3 exhibits the staff nurses' level of job satisfaction. As indicated in the table, the staff nurses were somewhat satisfied with their present work in the areas of professional work environment $(M=4.78)$ and professional relationships $(M=4.95)$. The staff nurses were somewhat satisfied that their work allowed them to contribute to the hospital and profession, which enabled them to use their full range of nursing skills, and provided a variety of challenges and opportunities to be of service to others. They were also satisfied in their present job because they received support and had good relationships with their supervisors, peers and physicians. They had sufficient time to complete patient physical care tasks, while receiving clear opportunities for advancement in the profession.

In contrast, the staff nurses were neutral when assessing their job satisfaction in terms of autonomy $(M=4.45)$, work worth $(M=4.50)$, role enactment $(M=4.34)$ and benefits $(M=4.23)$. They were unsure whether they were satisfied in their job when receiving praise for work well done from peers, physicians and nursing administrators, and whether they were able to have a voice in policy making for nursing services and the hospital. They still sought better opportunities for professional growth, salaries, adequate funding for healthcare, vacation and sick leave, and other in-service opportunities. Job satisfaction leads employees to be more productive, innovative and dedicated to maintaining the quality services provided to patients. Ean (2007) stated that job satisfaction has been extensively studied because it has a strong effect on productivity and service delivery, especially in healthcare, where nurses are the front line to quality services. Numerous studies have indicated that salary 
and working conditions are the most important factors to ensure the satisfaction of healthcare providers (Bodur, 2002). The current study's finding, which indicated a significant association between job satisfaction and working environment, is consistent with the findings of these previous studies.

\section{Is there a significant relationship between the nurse managers' leadership style, as perceived by the staff nurses, and the staff nurses' level of job satisfaction?}

Table 4: Relationship between Nurse Managers' Leadership Style, as Perceived by Staff Nurses, and Staff Nurses' Level of Job Satisfaction

\begin{tabular}{|c|c|c|c|c|c|c|}
\hline $\begin{array}{l}\text { Leadership style } \\
\text { (x-variable) }\end{array}$ & $\begin{array}{l}\text { Job } \\
\text { satisfaction } \\
\text { (y-variable) }\end{array}$ & $r$-value & Interpretation & $p$-value & Remarks & $\begin{array}{l}\text { Decision } \\
\text { on } \mathbf{H}_{0}\end{array}$ \\
\hline $\begin{array}{l}\text { Transform- } \\
\text { ational }\end{array}$ & \multirow{3}{*}{$\begin{array}{l}\text { Job } \\
\text { satisfaction }\end{array}$} & 0.258 & Low correlation & 0.000 & Sig. & Reject $\mathrm{H}_{0}$ \\
\hline Transactional & & 0.016 & $\begin{array}{l}\text { Negligible } \\
\text { correlation }\end{array}$ & 0.831 & Not sig. & Accept $\mathrm{H}_{0}$ \\
\hline Laissez-faire & & -0.204 & Low correlation & 0.006 & Sig. & Reject $\mathrm{H}_{0}$ \\
\hline
\end{tabular}

Table 4 displays the relationship between the nurse managers' leadership style, as perceived by the staff nurses, and the staff nurses' level of job satisfaction. When transformational leadership was correlated with the level of job satisfaction, it yielded an $r$-value of 0.258 , which connoted a low correlation with a $p$-value of 0.000 . Given that the $p$-value was less than the 0.05 level of significance, the null hypothesis was rejected, which meant there was a significant relationship between the transformational leadership style of the nurse managers, as perceived by the staff nurses, and the staff nurses' level of job satisfaction. This implies that, as the nurse managers often manifested a transformational leadership style, the staff nurses' level of job satisfaction slightly increased. Krishnan (2005) argued that the transformational leadership style encourages an organisation's employees to achieve more than they had planned. Here, this leadership style leads to transforming the followers' emotions, values and goals for specific performance based on their talent (Northouse, 2009).

Moreover, there was a significant relationship between laissez-faire leadership and level of job satisfaction, with a $p$-value of 0.006. The correlation coefficient of -0.204 indicated a negative correlation between variables. It can be inferred that, as the laissez-faire leadership style became apparent among nurse managers, the level of job satisfaction of the staff nurses decreased. However, there was no significant relationship between the nurse managers' transactional leadership and the staff nurses' level of job satisfaction, since the $p$-value was 0.006 . This suggests that, regardless of whether transactional leadership was displayed by nurse managers to their 
subordinates, the staff nurses' level of job satisfaction was neither boosted nor reduced.

Table 5: Relationship between Nurse Managers' Transformational Leadership Style, as Perceived by Staff Nurses, and Staff Nurses' Level of Job Satisfaction

\begin{tabular}{|l|l|l|l|l|l|l|}
\hline $\begin{array}{l}\text { Leadership } \\
\text { style } \\
\text { (x-variable) }\end{array}$ & $\begin{array}{l}\text { Job satisfaction } \\
\text { (y-variable) }\end{array}$ & $\boldsymbol{r}$-value & Interpretation & $\boldsymbol{p}$-value & Remarks & $\begin{array}{l}\text { Decision } \\
\text { on } \mathbf{H}_{\mathbf{0}}\end{array}$ \\
\hline $\begin{array}{l}\text { Transform- } \\
\text { ational } \\
\text { leadership }\end{array}$ & $\begin{array}{l}\text { Professional } \\
\text { work } \\
\text { environment }\end{array}$ & 0.248 & Low correlation & 0.001 & Sig. & Reject $\mathrm{H}_{0}$ \\
\cline { 2 - 7 } & Autonomy & 0.238 & Low correlation & 0.001 & Sig. & Reject $\mathrm{H}_{0}$ \\
\cline { 2 - 7 } & Work worth & 0.278 & Low correlation & 0.001 & Sig. & Reject $\mathrm{H}_{0}$ \\
\cline { 2 - 7 } & $\begin{array}{l}\text { Professional } \\
\text { relationships }\end{array}$ & 0.291 & Low correlation & 0.000 & Sig. & Reject $\mathrm{H}_{0}$ \\
\cline { 2 - 7 } & \begin{tabular}{l} 
Role enactment \\
\cline { 2 - 7 }
\end{tabular} & 0.178 & $\begin{array}{l}\text { Negligible } \\
\text { correlation }\end{array}$ & 0.016 & Sig. & Reject $\mathrm{H}_{0}$ \\
\cline { 2 - 7 } & Benefits job & $\mathbf{0 . 2 5 8}$ & Low correlation & $\mathbf{0 . 0 0 0}$ & Sig. & Reject $\mathrm{H}_{0}$ \\
\cline { 2 - 6 } & $\begin{array}{l}\text { Overall } \\
\text { satisfaction }\end{array}$ & 0.138 & Negligible & 0.062 & Not sig. & Accept $\mathrm{H}_{0}$ \\
\hline
\end{tabular}

Table 5 displays the relationship between the nurse managers' transformational leadership style, as perceived by the staff nurses, and the staff nurses' level of job satisfaction. Professional work environment received an $r$-value of 0.248 and $p$-value of 0.001 , autonomy had an $r$-value of 0.238 and $p$-value of 0.001 , work worth had an $r$-value of 0.278 and $p$-value of 0.001 and professional relationship had an $r$-value of 0.291 and $p$-value of 0.000 . These results all connoted a low correlation, thereby signifying that the null hypothesis should be rejected, and demonstrating a significant relationship. Given that the $p$-values were less than 0.05 , the null hypothesis was rejected. Further, role enactment received an $r$-value of 0.178 and $p$-value of 0.016 , which indicated a significant relationship; thus, the null hypothesis was rejected. Meanwhile, benefits received an $r$-value of 0.138 and $p$-value of 0.062 , which indicated negligible correlation. Given that the $p$-values were above 0.05 , the null hypothesis was accepted, and indicated no significant relationship. A recent study by Al-Harthi, Al Shehri, and Al Khatib (2013) indicated that the transformational leadership style positively influenced nursing performance in the workplace. Another related study in Taiwan revealed that transformational leadership contributed significantly to supervisor support. Notably, workplace support-particularly from the supervisor - was found to be an important mediator variable that explained the relationship between transformational leadership and job satisfaction (Lin, MacLennan, Hunt, \& Cox, 2015). 
Table 6: Relationship between Nurse Managers' Transactional Leadership Style, as Perceived by Staff Nurses, and Staff Nurses' Level of Job Satisfaction

\begin{tabular}{|c|c|c|c|c|c|c|}
\hline $\begin{array}{l}\text { Leadership } \\
\text { style } \\
\text { (x-variable) }\end{array}$ & $\begin{array}{l}\text { Job } \\
\text { satisfaction } \\
\text { (y-variable) }\end{array}$ & $r$-value & Interpretation & $p$-value & Remarks & Decision on $\mathrm{H}_{0}$ \\
\hline \multirow[t]{7}{*}{$\begin{array}{l}\text { Trans-actional } \\
\text { leadership }\end{array}$} & $\begin{array}{l}\text { Professional } \\
\text { work } \\
\text { environment }\end{array}$ & 0.037 & $\begin{array}{l}\text { Negligible } \\
\text { correlation }\end{array}$ & 0.618 & Not sig. & Accept $\mathrm{H}_{0}$ \\
\hline & Autonomy & 0.000 & $\begin{array}{l}\text { Negligible } \\
\text { correlation }\end{array}$ & 0.996 & Not sig. & Accept $\mathrm{H}_{0}$ \\
\hline & Work worth & 0.130 & $\begin{array}{l}\text { Negligible } \\
\text { correlation }\end{array}$ & 0.079 & Not sig. & Accept $\mathrm{H}_{0}$ \\
\hline & $\begin{array}{l}\text { Professional } \\
\text { relationships }\end{array}$ & 0.092 & $\begin{array}{l}\text { Negligible } \\
\text { correlation }\end{array}$ & 0.212 & Not sig. & Accept $\mathrm{H}_{0}$ \\
\hline & Role enactment & 0.026 & $\begin{array}{l}\text { Negligible } \\
\text { correlation }\end{array}$ & 0.722 & Not sig. & Accept $\mathrm{H}_{0}$ \\
\hline & Benefits & -0.129 & $\begin{array}{l}\text { Negligible } \\
\text { correlation }\end{array}$ & 0.080 & Not sig. & Accept $\mathrm{H}_{0}$ \\
\hline & $\begin{array}{l}\text { Overall job } \\
\text { satisfaction }\end{array}$ & 0.016 & $\begin{array}{l}\text { Negligible } \\
\text { correlation }\end{array}$ & 0.831 & Not sig. & Accept $\mathrm{H}_{0}$ \\
\hline
\end{tabular}

Table 6 displays the significant relationship between transactional leadership style and the level of job satisfaction among staff nurses. Professional work environment received an $r$-value of 0.037 and $p$-value of 0.618 , autonomy had an $r$-value of 0.000 and $p$-value of 0.996 , work worth had an $r$-value of 0.130 and $p$-value of 0.079 , professional relationship had an $r$-value of 0.092 and $p$-value of 0.212 , role enactment had an $r$-value of 0.026 and $p$-value of 0.722 , and benefits had an $r$-value of -0.129 and $p$-value of 0.080 . These results all connoted negligible correlation, which led to the decision to accept the null hypothesis, signifying no significant relationship between transactional leadership style and the level of job satisfaction among staff nurses.

Based on this analysis, the results are similar to the study conducted by Abualrub and Alghamdi (2012), in which they concluded, based on their results, that transformational leadership enhances nurses' job satisfaction levels, particularly in the areas of development, fair treatment and effective communication. Further, transactional leadership styles were negatively associated with job satisfaction, thereby indicating a preference for transformational leadership among nurse practitioners in Saudi Arabia. 
Table 7: Relationship between Nurse Managers' Laissez-faire Leadership Style, as Perceived by Staff Nurses, and Staff Nurses' Level of Job Satisfaction

\begin{tabular}{|l|l|l|l|l|l|l|}
\hline $\begin{array}{l}\text { Leadership } \\
\text { style } \\
\text { (x-variable) }\end{array}$ & $\begin{array}{l}\text { Job } \\
\text { satisfaction } \\
\text { (y-variable) }\end{array}$ & $\boldsymbol{r}$-value & Interpretation & $\boldsymbol{p}$-value & Remarks & Decision on $\mathbf{H}_{\mathbf{0}}$ \\
\hline $\begin{array}{l}\text { Laissez-faire } \\
\text { leadership }\end{array}$ & $\begin{array}{l}\text { Professional } \\
\text { work } \\
\text { environment }\end{array}$ & -0.175 & $\begin{array}{l}\text { Negligible } \\
\text { correlation }\end{array}$ & 0.018 & Sig. & Reject $\mathrm{H}_{0}$ \\
\cline { 2 - 7 } & Autonomy & -0.178 & $\begin{array}{l}\text { Negligible } \\
\text { correlation }\end{array}$ & 0.016 & Sig. & Reject $\mathrm{H}_{0}$ \\
\cline { 2 - 7 } & Work worth & -0.105 & $\begin{array}{l}\text { Negligible } \\
\text { correlation }\end{array}$ & 0.157 & Not sig. & Accept $\mathrm{H}_{0}$ \\
\cline { 2 - 7 } & $\begin{array}{l}\text { Professional } \\
\text { relationships }\end{array}$ & -0.189 & $\begin{array}{l}\text { Negligible } \\
\text { correlation }\end{array}$ & 0.010 & Sig. & Reject $\mathrm{H}_{0}$ \\
\cline { 2 - 7 } & \begin{tabular}{l} 
Role enactment \\
\cline { 2 - 7 }
\end{tabular} & $-\mathbf{- 0 . 1 9 3}$ & $\begin{array}{l}\text { Negligible } \\
\text { correlation }\end{array}$ & 0.009 & Sig. & Reject $\mathrm{H}_{0}$ \\
\cline { 2 - 7 } & $\begin{array}{l}\text { Benefits } \\
\text { Overall job } \\
\text { satisfaction }\end{array}$ & $-\mathbf{- 0 . 2 0 4}$ & Low correlation & 0.002 & Sig. & Reject $\mathrm{H}_{0}$ \\
\hline
\end{tabular}

Table 7 displays the relationship between laissez-faire leadership style and the level of job satisfaction among staff nurses. Professional work environment received an $r$-value of -0.175 and $p$-value of 0.018 , autonomy had an $r$-value of -0.178 and $p$-value of 0.016 , professional relationships had an $r$-value of -0.189 and $p$-value of 0.010 and role enactment had an $r$-value of -0.193 and $p$-value of 0.009 . These results all connoted an interpretation of negligible correlation, which led to the decision to reject the null hypothesis, and indicated a significant relationship between the laissez-faire leadership style and level of job satisfaction among staff nurses. Work worth had an $r$ value of -0.105 and $p$-value of 0.157 , which indicated negligible correlation, and showed no significant relationship, thereby accepting the null hypothesis. Benefits received an $r$-value of -0.2014 and $p$-value of 0.002 , which connoted a low correlation, and indicated a significant relationship; thus, the null hypothesis was rejected.

The recent study by Babola (2016) indicated that the laissez-faire leadership style is the least important predictor of organisational commitment, and $49.7 \%$ of variance was explained by the predictors $(F(3,67)=22.11, p<$ .001 ), with laissez-faire leadership style showing an increase of $13.2 \%$ of variance in organisational commitment. The full results indicated that job satisfaction $(\beta=.53, p<.001)$, the supervisor-subordinate relationship $(\beta=$ $.41, p<.001)$ and laissez-faire leadership style $(\beta=.38, p<.001)$ had a significant positive effect on organisational commitment. 


\section{Discussion}

This study aimed to determine the relationship between nurse managers' leadership styles and staff nurses' job satisfaction in hospital settings in Ha'il City. The findings of the study revealed that most participants were nurses from King Khalid Hospital, which comprised $45.1 \%$ of the total respondents, assigned in the ICU. The age of the majority of staff nurses ranged from 20 to 30 years $(n=120,65.2 \%)$, dominated by female Saudi nationals. These data indicated that nursing is and has always been a femaledominated profession (Huppatz, 2012). It was also notable that more than half of the respondents $(54.3 \%)$ held bachelor's degrees, compared with diploma graduate nurses $(44.6 \%)$. This result interestingly indicated improvement in the educational qualifications of staff nurses in Ha'il government hospitals, in contrast to previous studies, where more than half of the staff held a diploma (56\%), while $41 \%$ held a bachelor's degree (Alshammari, 2014). In terms of years of experience, $79.3 \%$ of the total respondents held experience of between one and 10 years, while $15.9 \%$ held experience of between 11 and 20 years. These data indicated that most of the staff nurses had been working as nurses for fewer than 10 years. This work experience occurred mostly in the Kingdom of Saudi Arabia, as reflected in the question regarding whether the respondents had gained overseas experience, to which the majority answered 'no' (69\%).

The leadership styles of the nurse managers, as perceived by the staff nurses, revealed that they fairly often displayed transformational leadership $(M=2.88)$, sometimes displayed transactional leadership $(M=2.31)$ and occasionally displayed laissez-faire leadership $(M=1.38)$. This result somewhat agreed with a previous study conducted in Riyadh regarding nurses' perceptions of their supervisors' leadership styles and outcome factors. These nurses held the perception that their supervisors more frequently used transformational and transactional, rather than laissez-faire, leadership styles (Abu-Tineh, Al-Omari, \& Khasawneh, 2008). In a similar study, where staff nurses rated their unit nurse managers' leadership styles using the MLQ, no unit nurse managers were rated by their staff as overwhelmingly using one leadership style over another. The unit nurse managers were rated as equally using all three leadership styles-transformational, transactional and passive/avoidant-with minor individual variances among the managers (Jaffe, 2012).

The following results were obtained from using the WQI to measure the staff nurses' level of job satisfaction. In terms of professional work environment (WQI numbers 1, 3 and 8), a mean response of 4.78 was interpreted as 'somewhat satisfied'. This aspect of work is an important indicator for quality patient care. A related study found that a high level of job satisfaction may be the result of a satisfactory work environment and adequate resources, which have positive effects on patients' perceptions. Additionally, 
the previous study revealed that patients' perceptions of the adequacy of resources were positively linked to nursing staff's evaluation of their workload (Alboliteeh, 2015). For autonomy (WQI numbers 3, 4 and 5), a mean result of 4.45 reflected a neutral response. For work worth (WQI number 2), a mean result of 4.50 indicated a neutral response. For professional relationships (WQI numbers 6 and 7), the mean result was 4.95, which reflected that, in this aspect, the staff nurses were somewhat satisfied. For role enactment (WQI number 4), the mean score was 4.34, which was interpreted as a neutral response. For the last aspect of benefits (WQI number 9), the mean result of 4.23 indicated a neutral response. This result implied the need for further investigations or future studies because the respondents seemed to be reluctant or did not fully express their opinions regarding their level of satisfaction with some aspects of their work. In a similar study, nurses revealed the main attributes of job satisfaction as follows: (i) fulfilment of desired needs within the work setting, (ii) happiness or gratifying emotional responses towards working conditions and (iii) job value or equity. These attributes were influenced by antecedent conditions, such as demographic, emotional, work characteristic and environmental variables. The consequences of nurses' job satisfaction have a significant effect on both nurses and patients (Bégat, Ellefsen, \& Severinsson, 2005).

Upon determining the relationship between the nurse managers' leadership style, as perceived by the staff nurses, and the staff nurses' level of job satisfaction, the following results were obtained. When transformational leadership correlated with the level of job satisfaction, it yielded an $r$-value of 0.258 , which connoted a low correlation with a $p$-value of 0.000 , which indicated a significant relationship between the nurse managers' transformational leadership style, as perceived by the staff nurses, and the staff nurses' level of job satisfaction. This implied that, as the nurse managers often manifested a transformational leadership style, the staff nurses' level of job satisfaction slightly increased. Krishnan (2005) argued that the transformational leadership style encourages organisations' employees to achieve more than they had planned. Here, this leadership style leads to transforming followers' emotions, values and goals for specific performance based on their talent (Northouse, 2009). Another study correlating job satisfaction and leadership behaviour-specifically transformational leadership - by Al-Hussami (2008) revealed a positive correlation of $n=55, r$ $(55)=.91, p<.05$. These results suggested that the predictor of transformational leadership accounted for an estimated $80 \%$ of the variance of job satisfaction.

Moreover, the current study identified a significant relationship between laissez-faire leadership and level of job satisfaction, with a $p$-value of 0.006 . The correlation coefficient of -0.204 indicated a negative correlation 
between variables. It could be inferred that, when the laissez-faire leadership style was apparent among nurse managers, the level of job satisfaction of staff nurses decreased. A recent study by Babalola (2016) indicated that laissezfaire leadership style is the least important predictor of organisational commitment, and $49.7 \%$ of variance was explained by the predictors $(F(3$, $67)=22.11, p<.001$ ), with laissez-faire leadership style showing an increase of $13.2 \%$ of variance in organisational commitment. The full results indicated that job satisfaction $(\beta=.53, \quad p<.001)$, the supervisor-subordinate relationship $(\beta=.41, p<.001)$ and laissez-faire leadership style $(\beta=.38$, $p<.001)$ had a significant positive effect on organisational commitment. This was confirmed by another study whose results revealed that the overall correlation between passive-avoidant leadership and job satisfaction was negative $(r=-0.240)$ (Abdelhafiz, Alloubani, \& Almatari, 2016).

However, the current study found no significant relationship between nurse managers' transactional leadership and staff nurses' level of job satisfaction, with a $p$-value of 0.006 . This suggests that, regardless of whether transactional leadership was displayed by nurse managers to their subordinates, the staff nurses' level of job satisfaction was neither boosted nor reduced. This result contrasts the study of Al-Hussami (2008), which yielded a positive correlation $(n=55, r(55)=.08, p>.05)$ between transactional leadership behaviour and job satisfaction. However, another study correlating job satisfaction and leadership styles revealed that staff nurses preferred transformational leadership style over transactional leadership style (Negussie \& Demissie, 2013).

\section{Conclusion and Recommendations:}

The results of this study indicated that staff nurses in Ha'il government hospitals perceived that nurse managers displayed transformational leadership behaviour more than transactional and laissez-faire leadership styles. In terms of the work features that provided them with satisfaction, the respondents were somewhat satisfied with the work environment and professional relationships; however, they were undecided in regard to their satisfaction on aspects such as autonomy, work worth, role enactment and benefits, as reflected in their neutral responses. Transformational leadership styles positively correlated with the nurses' job satisfaction.

\subsection{Recommendations}

The study findings suggest that hospital administrators should focus on developing nurse managers' transformational leadership behaviours through timely training and continuous education. In this manner, staff nurses' motivation and job satisfaction could be enhanced, which would lead to improved patient care and satisfaction. 


\section{References:}

1. Abdelhafiz, I. M., Alloubani, A. M. D., \& Almatari, M. (2016). Impact of leadership styles adopted by head nurses on job satisfaction: a comparative study between governmental and private hospitals in Jordan. Journal of nursing management, 24(3), 384-392.

2. Aboshaiqah, A., Hamdan-Mansour, A., Sherrod, D., Alkhaibary, A., \& Alkhaibary, S. (2014). Nurses' perception of managers' leadership styles and its associated outcomes. American Journal of Nursing Research, 2(4), 57-62 doi:10.12691/ajnr-2-4-1.

3. Abualrub, R., \& Alghamdi, M. (2012). The impact of leadership styles on nurses' satisfaction and intention to stay among Saudi nurses. Journal of Nursing Management, 20(5), 668-678.

4. Abu-Tineh, A. M., Al-Omari A. A., \& Khasawneh, A. (2008). Kouzes and Posner's transformational leadership model in practice: The case of Jordanian schools. Leadership \& Organization Development Journal, 29(8), 648-660.

5. Ahmad, A. R., Adi, M. N. M., Noor, H. M., Rahman, A. G. A., \& Yushuang, T. (2013). The influence of leadership style on job satisfaction among nurses. Asian Social Science, 9(9), 172.

6. Alboliteeh, M. (2015). Choosing to become a nurse in Saudi Arabia and the lived experience of new graduates: A mixed methods study. Retrieved from https://digital.library.adelaide.edu.au/dspace/bitstream/2440/92214/3/ 02whole.pdf

7. Al-Harthi, A., Al Shehri, O., \& Al Khatib, A. (2013). Leadership style among middle managers in Saudi Ministry of Health. European Scientific Journal, 9(26), 153-175.

8. Al-Hussami, M. (2008). A study of nurses' job satisfaction: The relationship to organizational commitment, perceived organizational support, transactional leadership, transformational leadership, and level of education. European Journal of Scientific Research, 22(2), 286-295.

9. Al-Mulhim, A. (2013). Saudi Youth, the Issue of Unemployment and Work Ethic. Arab News.

10. Al-Omari, A. (2008). The relationship between leadership styles of Hashemite University department chairs and job satisfaction as reported by department faculty members. University of Sharjah Journal for Humanities \& Social Sciences, 5(2), 101-124.

11. Al-Omari, A., Abdelwahed, H. S., \& Alansari, M. A. (2015). Critical care service in Saudi Arabia. Saudi Medical Journal, 36(6), 759. 
12. Alshammari, F. (2014). Nursing leadership in the Ministry of Health Hospitals of Saudi Arabia. Retrieved from https://researchbank.rmit.edu.au/eserv/rmit:160740

13. American Nurses Credentialing Center. (2012). Magnet recognition program model. Retrieved from http://www.nursecredentialing.org/

14. Amin, M., Shah, S., \& Tatlah, I. (2013). Impact of principals/directors' leadership styles on job satisfaction of the faculty members: Perceptions of the faculty members in a public university of Punjab, Pakistan. Journal of Research and Reflections in Education, 7(2), 97112.

15. Babalola, S. (2016). The effect of leadership style, job satisfaction and employee-supervisor relationship on job performance and organizational commitment. Journal of Applied Business Research, 32(3), 935. doi:10.19030/jabr.v32i3.9667. Retrieved from https://www.researchgate.net/publication

16. Bass, B. M., \& Avolio, B. J. (1990). Developing transformational leadership: 1992 and beyond. Journal of European industrial training, 14(5).

17. Bégat, I., Ellefsen, B. \& Severinsson, E. (2005). Nurses' satisfaction with their work environment and the outcomes of clinical nursing supervision on nurses' experiences of well-being-A Norwegian study. Journal of Nursing Management. Retrieved from http://onlinelibrary.wiley.com/woll/doi/10.1111/j.13652834.2004.00527.x/full

18. Breakey, S., Corless, I. B., Meedzan, N. L., \& Nicholas, P. K. (Eds.). (2015). Global health nursing in the 21st century. Springer Publishing Company.

19. Bodur, S. (2002). Job satisfaction of health care staff employed at health centers in Turkey. Occupational Medicine, 52, 353-355.

20. Bogler, R. (2001). The influence of leadership style on teacher job satisfaction. Educational administration quarterly, 37(5), 662-683.

21. Botelho, G. (2015). What's happening in the Middle East and why it matters. CNN Middle East. Retrieved from http://edition.cnn.com/2015/01/23/middleeast/middle-east-countrybreakdown/

22. Chen, J., \& Silverthorne, C. (2005). Leadership effectiveness, leadership style and employee readiness. Leadership \& Organization Development Journal, 260-288. doi:10.1108/01437730510600652.

23. Clavelle, J. T., Drenkard, K., Tullai-McGuinness, S., \& Fitzpatrick, J. J. (2012). Transformational leadership practices of chief nursing 
officers in Magnet organizations. The Journal of Nursing Administration, 42(4), 195-201.

24. Cox, K. B. (2003). The effects of intrapersonal, intragroup, and intergroup conflict on team performance effectiveness and work satisfaction. Nurse Admin Quarterly, 27(2), 153-163.

25. Despres, K. K. (2011). Perceived leadership styles of nurse managers' and nurses' job satisfaction: A correlational study(Doctoral dissertation, University of Phoenix).

26. Ean, L. B. (2007). Study on the job satisfaction and burnout among medical social workers in government hospitals in Malaysia. Master's thesis, University Sains Malaysia.

27. Huppatz, K. (2012). Gender and class in four occupations: Gender capital at work. UK: Palgrave Macmillan.

28. Jaffe, R. A. (2012). Staff Nurse Perception of Leadership Styles Among Nurse Managers.

29. Kleinman, C. (2004). The relationship between managerial leadership behaviors and staff nurse retention. Hospital Topics, 82(4), 2-9.

30. Krishnan, V. R. (2005). Transformational leadership and outcomes: Role of relationship duration. Leadership and Organization Journal, 26(5-6), 442-457.

31. Lin, P. Y., MacLennan, S., Hunt, N., \& Cox, T. (2015). The influences of nursing transformational leadership style on the quality of nurses' working lives in Taiwan: a cross-sectional quantitative study. $B M C$ nursing, 14(1), 33.

32. Madlock, P. E. (2008). The link between leadership style, communicator competence, and employee satisfaction. Journal of Business Communication, 45(1), 61-78. Retrieved from http://www.instituteforpr.org/supervisor-leadership-communicationcompetence-and-employee-satisfaction/

33. Mosadegh Rad, A. M., \& Yarmohammadian, M. H. (2006). A study of relationship between managers' leadership style and employees' job satisfaction. Leadership in Health Services, 19(2), 11-28. doi:10.1108/13660750610665008

34. Negussie, N., \& Demissie, A. (2013). Relationship between leadership styles of nurse managers and nurses' job satisfaction in Jimma University Specialized Hospital. Ethiopian Journal of Health Sciences, 23(1), 49-58.

35. Newstrom, J. W., \& Davis, K. (1993). Organizational behavior: Human behavior at work. New York, NY: McGraw-Hill.

36. Northouse, P. G. (2009). Leadership, theory and practice (5th ed.). US: Sage. 
37. Perez, J. W. L. (2014). Impact of nurse managers' leadership styles on staff nurses' intent to turnover. Retrieved from http://digitalcommons.gardner webb.edu/cgi/viewcontent.cgi?article $=1030 \&$ context=nursing_etd

38. Robbins, B., \& Davidhizar, R. (2007). Transformational leadership in health care today. The Health Care Manager, 26(3), 234-239.

39. Styron, R. A. Jr., \& Styron, J. L. (2017). Comprehensive problemsolving and skills development for next-generation leaders. IGI Global Book Series. ABSCA. Retrieved from https://books.google.com.sa/books?id=DZjgDQAAQBAJ\&pg

40. Taft, S. H. (2009). EMOTIONALLY INTELLIGENT LEADERSHIP IN NURSING ORGANIZATIONS. Management and Leadership for Nurse Administrators, 50.

41. Toker, B. (2011). Job satisfaction of academic staff: An empirical study on Turkey. Quality Assurance in Education, 19(2), 156-169. doi:10.1108/09684881111125050.

42. Watson, J. (2009). Caring science and human caring theory: Transforming personal and professional practices of nursing and health care. Journal of health and human services administration, 466-482.

43. Whitley, M. P., \& Putzier, D. J. (1994). Measuring nurses' satisfaction with the quality of their work and work environment. Journal of Nursing Care Quality, 8(3), 43-51.

44. Wood, N. E. (2008). A study on the relationship between perceived leadership styles of hospital clinical leaders and perceived empowerment, organizational commitment, and job satisfaction of subordinate hospital nurses in a management position (Doctoral dissertation, Capella University).

45. Wood, S., \& Peccei, R. (1995). Does TQM make a difference to employee attitudes? Employee Relations, 18(5), 45-48 